\title{
DIMINISHING THE VALUE OF WAR CRIMES PROSECUTIONS: A VIEW OF THE GUANTANAMO MILITARY COMMISSIONS FROM THE PERSPECTIVE OF INTERNATIONAL CRIMINAL LAW
}

\author{
Jonathan Hafetz ${ }^{*}$
}

\begin{abstract}
One of the most important questions in the current Guantanamo detainee litigation is whether the United States may prosecute individuals in military commissions for offenses that are not recognized as war crimes under international law. The United States maintains that such offenses-particularly, material support for terrorism and conspiracy-are violations of the 'US common law of war', a form of customary domestic liability in armed conflict distinct from international law. This paper offers a critique of the US theory from the perspective of international criminal law practice and theory. In particular, it explains how the US position unduly expands the conception of war crimes liability, thereby distorting the meaning of a war crime and undermining the value of prosecuting conduct on that basis.
\end{abstract}

\section{Keywords}

International criminal law, war on terror, legal tradition

\section{Introduction}

Since the 9/11 attacks, the United States has sought to prosecute terrorism suspects detained at the US Naval Base at Guantanamo Bay in military commissions. The fall-out from this legal experiment is still being experienced more than a decade later. The commissions, which are the subject of several court decisions and rounds of federal legislation, continue to raise an array of substantive and procedural issues. Among the most significant is the use of commissions to prosecute individuals for offences that are not recognized as war crimes under international law. The United States maintains that such offences-particularly, material support for terrorism and conspiracy-are violations of the "US common law of war', a form of customary domestic liability in armed conflict that is distinct

\footnotetext{
Associate Professor of Law, Seton Hall University School of Law. I would like to thank David Glazier, Kevin Jon Heller, Melanie O'Brien, and Michel Paradis for helpful comments on early drafts.
}

Copyright $\odot$ the Author(s).

This work is licensed under a Creative Commons Attribution-NonCommercial-NoDerivs 3.0 License. 
from international criminal liability. Since every pending military commission prosecution and every prior commission conviction (seven in total) has included the charge of material support for terrorism or conspiracy (or both), the issue has significant practical consequences for the existing system. More broadly, it raises important questions about the nature of war crimes and a state's ability to prosecute offences in a specially created tribunal outside its regular criminal justice system.

Military commissions have a long, but checkered history in the United States. ${ }^{1}$ While their use has generally been upheld, they have nonetheless generated concerns by jeopardizing the traditional supremacy of civilian authority over the military and the protection of the constitutional rights of the accused through the criminal process. ${ }^{2}$ Military commissions have thus historically been confined to martial law, occupied territory, and, in limited circumstances, offences that violate the international law of war. ${ }^{3}$

This paper examines military commissions from the perspective of legal traditions in conflict. It argues that the United States' common law of war theory presents a conflict between national and international conceptions of war crimes and criminal liability more generally. The US theory presents several problems. First, allowing individual countries to unilaterally define war crimes undermines the conception of war crimes as resting on shared ideals among nations. Second, the United States' common law of war theory effectively criminalizes any participation in armed conflict, undermining the idea of war crimes as exceptional and diluting the expressive value of war crimes prosecutions. Third, creating a specialized military tribunal to prosecute offences, such as material support for terrorism and conspiracy, that normally serve as the basis for federal terrorism prosecutions jeopardizes the principle of legality and the fair-trial guarantees established under international law and in prosecutions before international criminal tribunals.

\section{Prosecuting terrorism in military commissions}

The United States first established the post-9/11 military commissions through President George W. Bush's November 13, 2001 executive order, which autho-

1 L Fisher, Nazi Saboteurs on Trial: A Military Tribunal and American Law (2005); D Glazier, 'Kangaroo Court or Competent Tribunal?; Judging the 21st Century Military Commission' (2003) 89 Va LR 2005.

2 Ex parte Milligan, 71 US (4 Wall) 2 (1866).

3 Hamdan $v$ Rumsfeld, 548 US 557, 595-7 (2006) (Hamdan I). 
rized the military trial of foreign nationals who were members of al Qaeda or who had engaged in, aided and abetted, or conspired to commit a terrorist attack. ${ }^{4}$ The order proved highly controversial for several reasons, including the scope of liability, lack of procedural safeguards, and absence of congressional authorization. The Supreme Court invalidated these commissions in its 2006 decision in Hamdan $v$ Rumsfeld on separation of powers grounds (Hamdan I). ${ }^{5}$ The Court held that the commission convened to try the defendant, Salim Hamdan, violated a federal statute, the Uniform Code of Military Justice (UCMJ), which demands greater procedural parity between commissions and courts-martial, the regularly established US military courts. The UCMJ, moreover, conditioned the use of military commissions on compliance with the international law of war. The commission convened to try Hamdan, the Court found, violated at least one provision of the law of war: Common Article 3 of the Geneva Conventions, which prohibits 'the passing of sentences and the carrying out of executions without previous judgment pronounced by a regularly constituted court, affording all the judicial guarantees which are recognized as indispensable by civilized peoples' ${ }^{6}$ The majority opinion concluded that the commission failed to meet Common Article 3's 'regularly constituted court' requirement, while a plurality opinion further concluded that the commission neglected to provide 'all the judicial guarantees which are recognized as indispensable by civilized peoples' by allowing for the admission of coerced evidence and permitting the defendant's exclusion from his trial. The same plurality also concluded that the commission lacked authority to proceed because conspiracy-the sole charge against Hamdan-was not a war crime under international law.

Within months of the Supreme Court's decision, Congress enacted the Military Commissions Act of 2006 (2006 MCA), providing the legislative authorization that the Supreme Court had said was lacking. ${ }^{7}$ The 2006 MCA codified a range of offences as war crimes, including providing material support for terrorism (MST), conspiracy, and murder in violation of the law of war. In response to possible ex post facto concerns, the statute noted that it was merely codifying offences that have 'traditionally been triable by military commissions' and was

\footnotetext{
${ }^{4}$ Military Order of 13 November 2001: Detention, Treatment, and Trial of Certain Non-citizens in the War against Terrorism, 16 November 2001, 66 Fed Reg 57, 833.

5 See further H Keller \& M Forowicz, 'A New Era for the Supreme Court After Hamdan v Rumsfeld?' (2007) 67 ZaöRV 1.

${ }^{6}$ Geneva Convention Relative to the Treatment of Prisoners of War, 12 August 1949, 75 UNTS 135, Art 3 (Third Geneva Convention).

7 Military Commissions Act of 2006, Pub L No 109-366, 120 Stat 2600; 10 USC $\$ 948$ a (2006).
} 
not establishing any new crimes. In 2009, following President Obama's decision to maintain reformed military commissions, Congress enacted a second statute, the Military Commissions Act of 2009 (2009 MCA). ${ }^{8}$ Although the 2009 MCA provided additional procedural safeguards, including restrictions on the admission of hearsay and heightened protections against the use of coerced evidence, it maintained the same substantive offences. The legislation prompted concern among key Obama administration officials that at least some of those offences were not war crimes under international law, ${ }^{9}$ which could lead federal courts to reverse hard-won convictions and undermine the system's legitimacy. ${ }^{10}$ The 2009 MCA contained a similar ex post facto qualification, but further clarified that the listed offences had 'traditionally been triable under the law of war or otherwise triable by military commission', implicitly acknowledging that not all the offences were established international law violations. ${ }^{11}$

In 2008, a military commission convicted Salim Hamdan of providing MST and sentenced him to an additional five-and-one-half month in prison. David Hicks, the first Guantanamo detainee convicted before a military commission, had pled guilty to MST earlier that year. Although he was released from US custody, Hamdan appealed his conviction. ${ }^{12}$ In 2008, Ali al-Bahlul, who had served as a propagandist for al Qaeda, was convicted by a military commission on charges of conspiracy and solicitation as well as MST, and sentenced to life imprisonment. Al-Bahlul appealed. The Court of Military Commissions Review (CMCR) upheld both Hamdan and al-Bahlul's convictions. It recognized that the crime must violate some international norm to be prosecuted in a military commission, but concluded that the crimes charged against Hamdan and al-Bahlul violated international law. ${ }^{13}$ Both defendants sought review in the US Court of Appeals in the DC Circuit, the first Guantanamo military commission convictions to be reviewed by federal courts.

${ }_{8}^{8}$ Military Commissions Act of 2009, Pub L No 111-84, 123 Stat 2190; 10 USC $\$ 950$ p(d) (2009).

9 C Savage, 'U.S. Legal Officials Split Over How to Prosecute Terrorism Detainees', New York Times, 7 January 2013, <http://www.nytimes.com/2013/01/08/us/us-lawyers-divided-overprosecuting-terrorism-cases.html?_r=0 $>$ [accessed on 7 November 2013].

${ }^{10}$ Department of Justice (US), 'Statement of David Kris, Assistant Attorney General before the Senate Committee on Armed Services', 7 July 2009, <http://www.justice.gov/nsd/testi mony/2009/AAG-Kris-testimony-7-7-09.pdf> [accessed on 7 November 2013].

${ }^{11} 10$ USC $\$ 950 \mathrm{p}(\mathrm{d})$.

${ }^{12}$ Hicks did not appeal his conviction because the government had insisted that all those who plead guilty before military commissions - a total of five of the seven commission convictions to date-waive their right to appeal.

${ }^{13}$ United States v Al-Bahlul, 820 F.Supp 2d 1141 (CMCR, 2011). 
In defending Hamdan's conviction before the DC Circuit, the US government abandoned its contention that international law recognized MST as a war crime. It argued instead that because MST had long been recognized as a war crime under domestic law and practice, it could be tried by military commission. In Hamdan v United States (Hamdan II), the DC Circuit rejected the government's argument and reversed the conviction. ${ }^{14}$ It concluded that the 2006 MCA - the statute under which Hamdan was convicted-authorized the retroactive prosecutions only of offences prohibited as war crimes triable by military commission at the time those offences occurred. Hamdan was prosecuted for conduct occurring between 1996 and 2001. Such pre-2006 MCA conduct, the Court said, was controlled by Article 21 of the UCMJ, which permitted military commission jurisdiction over violations of the international law of war, not a separate domestic common law of war. International law, the DC Circuit concluded, did not recognize MST as a war crime at the time of Hamdan's alleged conduct (nor, it noted, does it currently recognize MST as a war crime). Accordingly, the Court ruled that the 2006 MCA did not authorize Hamdan's prosecution for MST for conduct pre-dating the statute and that to conclude otherwise would raise serious ex post facto problems under the US Constitution.

The DC Circuit subsequently vacated al-Bahlul's conviction for conspiracy and solicitation since the government acknowledged that international law does not consider those charges to be war crimes, making al-Bahlul's prosecution for pre-2006 MCA conduct impermissibly retroactive as well. ${ }^{15}$ The government sought en banc review before the full DC Circuit in al-Bahlul, although the gravamen of its challenge was to the DC Circuit's ruling in Hamdan II that commission jurisdiction over pre-2006 MCA conduct under the statute in effect at the time-Article 21 of the UCMJ-is limited to violations of the international law of war. The DC Circuit granted the request, and the case was heard by the full Appeals Court in the fall of 2013. No decision has yet been issued. In the interim, the commissions' chief prosecutor, Brigadier General Mark Martins, moved for the dismissal of conspiracy charges from all pending commission cases, including those involving the defendants implicated in the $9 / 11$ attacks and the destruction of the USS Cole in 2000, but his request was refused by the convening authority, which oversees the tribunal system. ${ }^{16}$

\footnotetext{
${ }^{14} 696$ F.3d 1238 (DC Cir, 2012).

${ }^{15}$ Al-Bahlul v United States, No 11-1324 (DC Cir, 2013).

${ }^{16}$ C Savage, 'Military Prosecutor Battles to Drop Conspiracy Charge in 9/11 Case', New York Times, 18 January 2013, <http://www.nytimes.com/2013/01/19/us/pentagon-wont-drop-conspiracycharge-against-khalid-shaikh-mohammed.html> [accessed on 7 November 2013].
} 
The United States' attempt to prosecute MST and conspiracy as war crimes before military commissions raises important constitutional questions. One such question is whether the Define and Punish Clause of Article I of the US Constitution ${ }^{17}$ restricts Congress' power to prosecute in military commissions violations of international law or whether, as the government maintains, Congress may also authorize punishment of offences traditionally tried under a separate US common law of war. Even if Congress has that power, another issue is whether prosecuting non-international law of war violations in military commissions violates the jury trial guarantee of Article III and the Fifth and Sixth Amendments to the Constitution, which protect a defendant's right to a criminal trial in civilian court. Because the DC Circuit interpreted 2006 MCA as retroactively authorizing prosecution only of international law of war violations, it did not address the permissible scope of congressional power or other constitutional limits on military commission jurisdiction. However, Judge Kavanaugh, who authored the panel opinion in Hamdan II, suggested in a concurring footnote-that neither of the other two panel members joined-that Congress could, consistent with Article I, authorize the trial of offences that do not violate international law. ${ }^{18}$ Judge Kavanaugh maintained that Congress's war powers 'are not defined or constrained by international law', and that the United States could 'be a leader in the international community' by authorizing war against a terrorist organization and expanding the category of war crimes beyond those recognized under international law. These issues will have to be confronted if the full DC Circuit or the Supreme Court concludes that the 2006 MCA applies retroactively or if the current-or a future-administration decides to charge other terrorism suspects in military commissions for post-2006 MCA conduct. Indeed, the government has contemplated using a military commission in at least one such case. ${ }^{19}$ The US common law of war theory thus suggests the possibility of a shadow military court system in which Congress is free to define war crimes outside of international law and to have them adjudicated in military commissions rather than in Article III courts.

This paper does not address these constitutional issues, but rather examines

${ }^{17}$ US Constitution, Art I, $\$ 8, \mathrm{cl} 10$. The clause provides that Congress shall have the power " $\mathrm{t}$ ] define and punish piracies and felonies committed on the high seas, and offenses against the law of nations.'

${ }^{18}$ Hamdan II, 480.

${ }^{19}$ C Savage, 'Prisoner in Iraq Tied to Hezbollah Faces U.S. Military Charges', New York Times, 23 February 2012, <http://www.nytimes.com/2012/02/24/world/middleeast/us-approvesmilitary-tribunal-case-for-detainee.html> [accessed 7 November 2013] (reporting that the Obama administration approved military commission charges against Ali Musa Daqduq for murder, terrorism, and other war crimes committed during an insurgency in 2007). 
the US common law of war theory from perspective of conflicting legal traditions. The sections below describe: (1) how the creation of a separate branch of domestic war crimes liability threatens the conception of shared norms underlying international criminal law; (2) how offences such as MST and conspiracy would significantly expand war crimes liability and undermine the conception of a war crime itself; and (3) how military commissions threaten international criminal law principles of legality through the retroactive imposition of liability and the diversion of prosecutions to a forum that provides defendants significantly fewer protections than the existing domestic court system which is capable and willing to prosecute the offences.

\section{The US common law of war and international law}

International law rests on a consensus among nations regarding shared values and norms, and not on a particular country's unique heritage or tradition. Early modern theorists such as Pufendorf and Vattel viewed the establishment of international standards as important to both peace and prosperity. As Vattel explained, nations must 'reciprocally conform to general rules' to prevent resorting to violence and war. ${ }^{20}$ This notion of shared norms-and of membership in a larger community-is central to international law and to conceptions of its role in constraining state behaviour. ${ }^{21}$

A defining feature of international criminal law is that its scope is limited to crimes of exceptional severity. As Margaret de Guzman has observed, "[ $t$ ]he gravity of international crimes is the [...] primary conceptual foundation of international law's authority to administer criminal justice.2 ${ }^{22}$ In addition to establishing a basis for liability, shared ideals regarding crime severity have important jurisdictional consequences. ${ }^{23}$ They provide the basis for prosecuting individuals in an international forum and imposing liability even over the opposition of concerned states. Those ideals also potentially authorize any state to prosecute certain offences under principles of universal jurisdiction, even if

\footnotetext{
${ }^{20}$ E de Vattel, The Law of Nations (1797) III.viii.\$137.

${ }^{21}$ P Margulies, 'Defining, Punishing, and Membership in the Community of Nations: Material Support and Conspiracy Charges in Military Commissions' (2013) 36 Fordham Int LJ 1.

${ }^{22}$ M M deGuzman, 'How Serious Are International Crimes? The Gravity Problem in International Criminal Law' (2012) 51 Columbia J Transnat'l L 18, 19.

${ }^{23}$ A K A Greenawalt, 'The Pluralism of International Criminal Law' (2011) 86 In LJ 1063, 1095.
} 
those offences would otherwise fall outside the jurisdiction of their national courts. $^{24}$

War crimes are among the oldest offences under international law. ${ }^{25}$ They have developed over the centuries through custom and usage, reflecting an evolving consensus on conduct so extreme it is prohibited even during armed conflicts, where state-sponsored violence is the generally accepted norm. ${ }^{26}$ Further, the Rome Statute suggests that not all war crimes are equal, giving the International Criminal Court (ICC) jurisdiction over war crimes in particular when committed as part of a plan or policy or as part of a large-scale commission of such crimes. ${ }^{27}$

A separate 'US common law of war' jeopardizes the principle that war crimes rest on shared conceptions of exceptionally grave conduct. It suggests that each state may unilaterally define its own sub-set of war crimes, creating the possibility of multiple and inconsistent definitions of criminal liability during armed conflict.

International criminal law, to be sure, is evolving. It has been described as a hybrid-'public international law impregnated with notions, principles, and legal constructs derived from national criminal law, [international humanitarian law], as well as human rights law. ${ }^{28}$ Disagreement persists over international criminal law's parameters, particularly on issues surrounding collective guilt and vicarious liability. Holding individuals liable for substantive crimes perpetrated by others has been controversial since Nuremberg and remains so today. ${ }^{29}$

But while states may disagree at the margins, legitimate international prosecutions are now limited to those offences broadly understood to constitute international criminal law violations. One of the main achievements of the Rome Statute has been to define a set of widely accepted international crimes, including war crimes. Any state wishing to prosecute offences beyond those contained in the Statute should bear the burden of demonstrating that the particular offence is widely accepted by the international community as a recognized violation of international criminal law or is validly proscribed by national law and falls within

\footnotetext{
${ }^{24}$ Ibid.

${ }^{25}$ W Schabas, An Introduction to the International Criminal Court (2007) 65.

${ }^{26}$ Sosa v Alvarez-Machain, 542 US 692, 732 (2004) (classifying war crimes as among a narrow 'handful of heinous actions-each of which violates definable, universal, and obligatory norms').

${ }^{27}$ Rome Statute of the International Criminal Court, 17 July 1998, 2187 UNTS 90, Art 8 (Rome Statute).

${ }^{28}$ A Cassese, International Criminal Law ( $2^{\text {nd }}$ edn, 2008) 7.

${ }^{29}$ J D Ohlin, 'Joint Intentions to Commit International Crimes' (2011) 11 Chicago JIL 693.
} 
the legitimate scope of national jurisdiction.

The United States does not argue that MST or conspiracy-which both ground liability on theories of vicarious responsibility-are offences under international law. It is not, in other words, offering a competing interpretation of a shared norm of substantive criminal liability. Rather, it is seeking to prosecute individuals based on what it claims is a separate domestic tradition of war crimes that exists outside of and independent from internationally accepted norms.

The domestic common law of war theory is another manifestation of the United States' view that international law should not constrain its ability to wage a global armed conflict against al Qaeda and associated terrorist organizations (the so-called 'war on terror'). This unilateralist impulse underlay US interrogation practices after 9/11, in which the harsh, often brutal treatment of detainees was premised on the theory that they fell outside the Geneva Conventions because they were members or supporters of a non-state terrorist organization. ${ }^{30}$ The Supreme Court ultimately rejected this position in Hamdan I, determining that at a minimum Common Article 3 applies to all individuals in US custody, ${ }^{31}$ and the Obama administration has sought to reform US interrogation practices along those lines. ${ }^{32}$ But the impulse to avoid international law persists through the United States' effort to prosecute terrorism suspects in military commissions under its theory of a domestic common law of war.

\section{The military commissions' expansive notions of liability undermine the theory and expressive value of war crimes under international criminal law}

The US common law of war theory posits a sweeping expansion of individual criminal liability during armed conflict. Under the guise of domestic law, it seeks to bring within the scope of war crimes conduct that exceeds even the broadest notions of collective liability articulated by international tribunals since Nuremberg. Under international law, war crimes are considered grave offences and liability is premised on personal culpability. The US common law of war theory, however, turns this notion on its head. It seeks to impose liability for

\footnotetext{
${ }^{30} \mathrm{~J}$ Hafetz, Habeas Corpus after 9/11: Confronting America's New Global Detention System (2011).

${ }^{31}$ Hamdan I, 629.

${ }^{32}$ Executive Order No 13,491: 'Ensuring Lawful Interrogations,' 22 January 2009, 74 Fed Reg 4893.
} 
virtually any participation in armed conflict and effectively transforms all enemy fighters into war criminals, even if they do not themselves participate in or commit a war crime. The theory diminishes the expressive value of war crimes prosecutions and is in tension with the aim of international criminal justice to stigmatize only the most egregious conduct as meriting the label of war crime.

\subsection{Conspiracy and MST}

The charges of MST and conspiracy underscore the unprecedented scope of war-crimes liability in military commissions, as does the charge of murder in violation of the law of war, which was the main issue in the prosecution of Canadian detainee Omar Khadr.

The MCA makes it a war crime to provide material support to a terrorist organization engaged in hostilities against the United States, including financial assistance, training, expert advice or assistance, and personnel. ${ }^{33}$ The MCA's definition of material support borrows directly from the federal MST statute, which is frequently used to prosecute terrorism suspects in federal court. ${ }^{34}$ By criminalizing 'support', the MCA does not require that the defendant participate in a specific terrorist attack or otherwise engage in conduct in violation of the law of war. Hamdan, for example, was convicted of MST based on evidence that he had served as Osama bin Laden's personal driver before 9/11 and was captured in November 2001 in Afghanistan while driving a car containing two anti-aircraft missiles and an al Qaeda-issued document authorizing the bearer to carry a weapon in Afghanistan. Another Guantanamo detainee, Noor Mohammed, pled guilty to MST charges in a commission prosecution based on his having served as a trainer at an al Qaeda-affiliated military training camp. ${ }^{35}$ Neither individual was accused of committing or assisting in the commission of a terrorist act nor of otherwise engaging in a war crime under international law.

The Defense Department has similarly used the charge of conspiracy to prosecute individuals in military commissions for their support for and connection to al Qaeda without showing that they sought to commit or participated in the commission of a war crime. The MCA covers any conspiracy to commit one or more of the substantive offences triable by military commission under the act,

\footnotetext{
3310 USC $\$ 950 t(25)$.

3418 USC \$\$2339A, 2339B. On federal prosecutors' use of the MST statutes, see R B Zabel \& J J Benjamin Jr, In Pursuit of Justice: Prosecuting Terrorism Cases in the Federal Courts (2008).

${ }^{35}$ Charge Sheet for Noor Uthman Mohammed, 23 May 2008, <http://www.defense.gov/news/M ay2008/d20080523mohammedsworn.pdf $>$ [accessed 7 November 2013].
} 
as long as there is some overt act to effect the conspiracy's object. ${ }^{36}$ The MCA's broad language encompasses conspiracy both as a stand-alone criminal offence and a form of vicarious criminal liability. Under the former, an individual may be held liable for the inchoate crime of agreeing to commit unlawful acts, regardless of whether those acts are actually committed. Liability thus typically attaches for agreeing to join a criminal organization with the intention of furthering its purpose, and committing some minor overt act in furtherance of that purpose. Under the latter formulation, some other substantive crime has been committed, and an individual is held vicariously liable for that underlying substantive offence committed by his co-conspirators as long as it was reasonably foreseeable. ${ }^{37}$

Following the enactment of the 2006 MCA, the government charged Hamdan with conspiracy based on the allegation that he had join[ed] an enterprise of persons' that shared a 'common criminal purpose' to commit a variety of criminal acts. $^{38}$ It charged another Guantanamo detainee, Ibrahim Ahmed Mahmoud al Qosi, with conspiracy for conducting arms training and periodically serving as Osama bin Laden's driver and bodyguard in 2001. ${ }^{39}$ It charged Sufyian Barhoumi with conspiracy for receiving explosives training from and later becoming an explosives trainer for al Qaeda. ${ }^{40}$ The government's conspiracy charge against al-Bahlul centred on his working in al Qaeda's media office before 9/11, during which time he helped prepare propaganda videos for the organization.

In none of these cases, including al-Bahlul's, did the government allege that the defendant committed or directly participated in a violation of the law of war. These cases are illustrative of the prosecution charge sheets in most military commission cases in that they assert a conspiracy to commit war crimes by inferring a defendant's 'agreement' from his alleged association with al Qaeda members and acts in support of the organization. The charge sheets typically do not allege the commission of any underlying substantive offence. ${ }^{41}$

Military commission charges of conspiracy and MST exceed even the most

\footnotetext{
${ }^{36} 10$ USC $\$ 950 t(28)$.

${ }^{37}$ See R Wala, From Guantanamo to Nuremberg and Back: An Analysis of Conspiracy to Commit War Crimes under International Humanitarian Law' (2010) 41 Georgetown JIL 683, 685-7.

${ }^{38}$ Although Hamdan was charged under the prior, 2006 version of the MCA, the statute's definition of conspiracy did not change when it was amended in 2009. The commission acquitted Hamdan of the conspiracy charge, convicting him only on the material support count.

${ }^{39}$ Charge Sheet for Ibrahim Ahmed Mahmoud al Qosi, 8 February 2008, <http://www.def ense.gov/news/d20080305alqosicharges.pdf> [accessed 7 November 2013].

${ }^{40}$ Charge Sheet for Sufyian Barhoumi, 29 May 2008, <http://www.defense.gov/news/d200805 29Sufyian.pdf $>$ [accessed 7 November 2013].

${ }^{41}$ See e.g. Wala, above $\mathrm{n} 37,686$.
} 
controversial forms of vicarious liability under international law. MST has never been recognized as a war crime in an international tribunal, and the US effort to treat it as such at Guantanamo is unprecedented. ${ }^{42}$ The argument against conspiracy liability is in a sense even clearer, as it has been considered and rejected as a basis for war crimes prosecution under international treaties and by international tribunals. Conspiracy's attempted resuscitation highlights how the United States is using military commissions to circumvent international-law limitations on collective and vicarious criminal responsibility.

Vicarious and membership-based liability theories proved highly contentious in criminal prosecutions after World War II. ${ }^{43}$ Their proponents, including Murray C Bernays, a lawyer in the US War Department, saw conspiracy as a legal vehicle for obtaining mass convictions. ${ }^{44}$ As Bernays observed, once a conspiracy had been established among the Nazi government and its party and state agencies, 'each act of every member thereof during its continuance and in furtherance of its purposes would be imputable to all other members thereof. ${ }^{4}$ The International Military Tribunal at Nuremberg (IMT) nonetheless refused to recognize conspiracy to commit war crimes as an offence in violation of the law of war despite some ambiguity in the London Charter and over the prosecution's objections. ${ }^{46}$ Tribunal members resisted recognizing conspiracy as a war crime not merely because " $t$ ] he Anglo-American concept of conspiracy was not part of European legal systems and arguably not an element of the internationally recognized laws of war. ${ }^{47}$ They also believed that the malleability of conspiracy-based liability could lead to prosecutorial abuses and drag innocent people into the prosecution's net, ${ }^{38}$ thus jeopardizing the trials' legitimacy. ${ }^{49}$ The criminal tribunals conducted by the Allied Powers after the IMT under

\footnotetext{
42 J Vanzant, 'No Crime without Law: War Crimes, Material Support for Terrorism, and the Ex Post Facto Principle' (2010) 59 DePaul LR 1053.

${ }^{43}$ S Pomorski, 'Conspiracy and Criminal Organizations', in G Ginsburgs \& V N Kudriavtsev (eds), The Nuremberg Trial and International Law (1990) 229.

${ }^{44}$ A Danner \& J S Martinez, 'Guilty Associations: Joint Criminal Enterprise, Command Responsibility, and the Development of International Criminal Law' (2005) 93 Ca LR 75, 114.

${ }^{45}$ M Bernays, 'Subject: Trial of European War Criminals', in B F Smith (ed), The American Road to Nuremberg: The Documentary Record 1944-1945 (1982) 33, 36-7.

${ }^{46}$ Hamdan I, above n 3, 610-11; HM Attorney-General, The Trial of German Major War Criminals (1949) 21 (IMT Judgment); Charter of the International Military Tribunal, 8 August 1945, 82 UNTS 284, Art 9.

${ }^{47}$ T Taylor, Anatomy of the Nuremberg Trials: A Personal Memoir (1992).

${ }^{48}$ Ibid, 553.

${ }^{49}$ See Danner \& Martinez, above n 44, 115.
} 
Control Council Law No 10 also declined to treat conspiracy as a war crime. ${ }^{50}$ The Charter for the International Military Tribunal for the Far East (IMTFE), charged with prosecuting members of the Japanese government following World War II, likewise refused to confer jurisdiction over a conspiracy to commit any crime except a crime against the peace. ${ }^{51}$ The Nuremberg Principles, drafted to memorialise the lessons from the World War II prosecutions, exclude conspiracy from its list of war crimes and further state as a core principle that only '[c]omplicity in the commission of [...] a war crime [...] is a crime under international law' ${ }^{52}$

The IMT did declare certain organizations criminal based on a separate provision of the London Charter, ${ }^{53}$ thus facilitating membership-based prosecutions under Control Council Law No 10. But the IMT sought to limit organizational liability based on the principle that 'criminal guilt is personal'.54 Membership offences prosecuted in subsequent Nuremberg tribunals were thus confined to senior officials whose organizational roles and activities tied them to the commission of war crimes and to individuals who participated in some way in advancing the organization's criminal purpose. Moreover, the Nuremberg-era criminal membership precedents have since been criticized and do not reflect the current status of international law. ${ }^{55}$

Post-Nuremberg developments reinforce the international consensus against imposing conspiracy liability for war crimes. The Geneva Conventions of 1949 and Additional Protocols of 1977 do not recognize liability for conspiracy to commit war crimes. ${ }^{56}$ Neither does the Statute for the ICC nor do the Statutes for the International Criminal Tribunal for the Former Yugoslavia (ICTY) or the International Criminal Tribunal for Rwanda (ICTR), even though the latter both

\footnotetext{
${ }^{50}$ Trials of War Criminals Before the Nuremberg Military Tribunals under Control Council Law No 10, vol 15 (1949), 1077-1080.

${ }^{51}$ IMT Judgment, International Military Tribunal for the Far East 48 (1948) 413, 449-51.

52 Principles of International Law Recognized in the Charter of the Nürnberg Tribunal and in the Judgment of the Tribunal, ILC Ybk 1950/II, 377.

${ }^{53}$ See IMT Judgment, 67-83.

${ }^{54}$ Ibid, 67.

${ }^{55}$ K Heller, 'Criminal Membership's Lack of Precedential Value', Opinio Juris, 12 September 2011, <http://opiniojuris.org/2011/09/12/criminal-memberships-lack-of-precedential-value/> [accessed 7 November 2013].

${ }^{56}$ Convention (IV) Relative to the Protection of Civilian Persons in Time of War, 12 August 1949, 75 UNTS 287, Arts 146-47 (Fourth Geneva Convention); Protocol Additional to the Geneva Conventions of 12 August 1949, and Relating to the Protection of Victims of International Armed Conflicts, 8 June 1977, 1125 UNTS 3.
} 
include conspiracy liability for genocide. ${ }^{57}$

International criminal law, to be sure, continues to struggle with the contours of vicarious liability, as debates over the scope of the Joint Criminal Enterprise (JCE) doctrine suggest. Like conspiracy, JCE provides a way to hold individuals responsible for their role in group criminality. Although the ICTY Statute does not specifically include JCE, judges have found that the Statute implicitly permits holding a defendant liable for his participation in crimes committed pursuant to a common plan or design, even if the defendant did not perpetrate the offence itself. $^{58}$ The Rome Statute expressly provides for criminal liability where a person 'contributes to the commission or attempted commission of [...] a crime by a group of persons acting with a common purpose. ${ }^{59}$ Under JCE III, the doctrine's most expansive incarnation, individuals may be held liable for the acts of others that fall outside the scope of the common criminal plan but that are nevertheless reasonably foreseeable. ${ }^{60}$

JCE has properly been criticized for allowing overly expansive forms of liability that erode the principle of personal culpability and have the potential to slip into a form of guilt by association. ${ }^{61}$ But even in its broadest form, JCE remains a mode of participation-a way to prove an individual's perpetration of serious crimes and 'not a crime in itself' ${ }^{62}$ It requires a completed substantive war crime, such as wilful killing, that is committed pursuant to a common plan or scheme and by a perpetrator with the intent to execute that scheme. ${ }^{63} \mathrm{JCE}$ is not a stand-alone inchoate crime, and does not support the type of liability that conspiracy can for mere criminal agreements. ${ }^{64} \mathrm{JCE}$, moreover, not only imposes

\footnotetext{
${ }^{57}$ Statute of the International Criminal Tribunal for the Former Yugoslavia, SC Res 827, 25 May 1993, Art 4(3)(b); Statute of the International Tribunal for Rwanda, SC Res 955, 8 November 1994, Art 2(3)(b). The international community's acceptance of conspiracy liability for genocide may be explained by the sheer magnitude of the wrongdoing and the intricate, elaborate, and systemic planning necessary to carry it out.

${ }^{58}$ Prosecutor v Vasiljevic (Judgment) (ICTY, Appeals Chamber, Case No IT-98-32-A, 25 February 2004) paras 94-101.

${ }^{59}$ Rome Statute, Art 25(3)(d).

${ }^{60}$ Prosecutor v Tadić (Judgment) (ICTY, Appeals Chamber, Case No IT-94-1-A, 15 July 1999) para 220 (Tadić).

${ }^{61}$ See Danner \& Martinez, above n 44, 132-37.

${ }^{62}$ Prosecutor v Kvočka (Judgment) (ICTY, Appeals Chamber, Case No IT-98-30/1-A, 28 February 2005) para 91.

${ }^{63}$ Tadić, para 189-90.

${ }^{64}$ Rwamakuba v Prosecutor (Decision on Interlocutory Appeal Regarding Application of Joint Criminal Enterprise to the Crime of Genocide) (ICTR, Appeals Chamber, Case No ICTR-98-44-AR72.4, 22 October 2004) para 30.
} 
a higher mens rea requirement than conspiracy, but also requires an actus reus that has some causal relationship to the war crime, in contrast to the relatively minor and insubstantial 'overt act' that furthers the goal of the conspiracy, independent of its causal relationship to the war crime. ${ }^{65}$ JCE liability thus remains narrower than conspiracy-based liability under the MCA, which can be imposed based on a person's participation in or support for al Qaeda unconnected to the commission of a substantive offence. ${ }^{66}$

\subsection{Murder in violation of the law of war}

The potential scope of liability under the US common law of war is perhaps most dramatically illustrated by the government's interpretation of the MCA offence of murder in violation of the law of war. ${ }^{67}$ This was the principal charge against Omar Khadr. ${ }^{68}$ While the MCA does not define violations of the law of war, the Military Commissions Manual, which provides guidance to the Defense Department in interpreting the MCA, says that an accused may be convicted by a military commission if he engaged in conduct 'traditionally triable by military commission (e.g., spying; murder committed while the accused did not meet the requirements of privileged belligerency) even if such conduct does not violate the international law of war. 69 The prosecution alleged that Khadr violated the law of war by intentionally throwing a hand grenade during a firefight that led to the death of a US Army Special Forces officer in Afghanistan. ${ }^{70}$ Khadr ultimately pled guilty in exchange for a promise to transfer him to Canada to serve out the

\footnotetext{
${ }^{65}$ Wala, above n 37, 704 .

${ }^{66}$ Cassese, above n 28, 33.

${ }^{67} 10$ USC $\$ 950 \mathrm{v}(\mathrm{b})(15)$.

${ }^{68}$ Charge Sheet for Omar Ahmed Khadr, 6 April 2007, <http://www.law.utoronto.ca/doc uments/Mackin/Kuebler_ExhibitA.pdf> [accessed 7 November 2013].

${ }^{69}$ Manual for Military Commissions (2012) IV-13. Although a prior version of the Manual was in effect at the time of Khadr's prosecution, this provision of the Manual did not change when it was updated in 2012. Thus, acting as a combatant, or directly taking part in hostilities, is deemed a war crime, if done by an unprivileged belligerent. See D Frakt, 'Direct Participation in Hostilities as a War Crime: America's Failed Efforts to Change the Law of War' (2012) 46 Val U LR 727, 738.

${ }^{70}$ It also charged Khadr with conspiracy and material support for terrorism based on allegations that he received weapons training, engaged in surveillance and reconnaissance against the US military, and took part in converting and planting improvised explosive devices (IEDs). See Glazier, 'Still a Bad Idea: Military Commissions under the Obama Administration,' Loyola Law School of Los Angeles, Legal Studies Paper No 2010-32, <http://ssrn.com/abstract=1658590> [accessed 7 November 2013].
} 
remainder of his eight-year sentence. ${ }^{71}$

The theory behind Khadr's prosecution portends a radical expansion of war crimes liability. International humanitarian law $(I H L)$ sanctions the use of force both by and against combatants during armed conflict, as long as they meet the requirements for lawful combatants, which include operating under a legally accountable chain of command, identifying themselves through a uniform or emblem, displaying their arms openly, and adhering to the laws of war. ${ }^{72}$ Under international law, lawful combatants enjoy a privilege of belligerency, which protects them from domestic criminal prosecution for killing or wounding members of an opposing force. International law, however, also regards lawful combatants as legitimate targets for the opposing force during the armed conflict.

By contrast, individuals who do not qualify as lawful combatants cannot invoke the combatant's privilege. Since al Qaeda does not meet these requirements, its members would not qualify as lawful combatants, but instead would be treated as unprivileged belligerents.

In contrast to a lawful combatant, an unprivileged belligerent such as Khadr does not have immunity under international law for engaging in legitimate acts of warfare, such as throwing a hand grenade at an enemy soldier during a firefight. But international law also does not criminalize the ordinary killing of combatants, even if carried out by an unprivileged belligerent. ${ }^{73}$ Khadr could thus have been prosecuted for murder under either Afghan or US criminal law. ${ }^{74}$ Khadr cannot, however, be prosecuted under international law unless his conduct itself constitutes a war crime-for example, if he had used a prohibited weapon or deliberately targeted civilians. ${ }^{75}$

Charging Khadr with a war crime for an otherwise legitimate use of military force during armed conflict contradicts black-letter IHL. It transforms a conduct-based-liability rule into a status-based rule. It rests, moreover, on a theory that all potentially lethal uses of force by unprivileged belligerents are war

${ }^{71}$ I Austen, 'Sole Canadian Held at Guantánamo Bay Is Repatriated', New York Times, 29 September 2012, <http://www.nytimes.com/2012/09/30/world/americas/canadian-held-at-guantanamobay-is-repatriated.html?_r=0> [accessed on 7 November 2013].

${ }^{72}$ Regulations Concerning the Laws and Customs of War on Land, 29 July 1899, 187 CTS 227, Art 1 (Annex, Hague II).

${ }^{73}$ Y Dinstein, The Conduct of Hostilities under the Law of International Armed Conflict (2004) 31; G D Solis, The Law of Armed Conflict (2010) 211.

${ }^{74} \mathrm{~J}$ C Hanson, 'Murder and the Military Commissions: Prohibiting the Executive's Unauthorized Expansion of Jurisdiction' (2009) 93 Mn LR 1871, 1882-3.

${ }^{75}$ See M Schmitt, 'Humanitarian Law and Direct Participation in Hostilities by Private Contractors or Civilian Employees' (2005) 5 Chi J Int'l L 511, 520-21. 
crimes. Any member of an enemy force in the conflict against al Qaeda or its affiliates who, for example, shoots back at a US soldier during a firefight is thus by definition subject to prosecution as a war criminal.

\subsection{Implications of the US theory of war crimes in the war on terror}

The Guantanamo military commissions represent significant departure from existing notions of criminal liability during armed conflict and from the conception of a war crime itself. As David Glazier has observed, charges of MST, conspiracy, and murder in violation of the law of war effectively collapse the distinction between jus ad bellum and jus in bello that is central to the law of armed conflict. ${ }^{76}$ Jus ad bellum rules regulate the decision to use force and can subject to prosecution those responsible for deciding to unlawfully commence hostilities, as demonstrated by the use of 'crimes against the peace' at the Nuremberg and Tokyo tribunals after World War II and the inclusion of the crime of aggression under the jurisdiction of the ICC. Jus in bello rules, which govern the actual conduct of the war, assign combatants on both sides equal rights and responsibilities, imposing liability based on individual conduct and not the justness of one side's cause. $^{77}$

The Guantanamo military commissions, by contrast, can impose liability based solely on the decision to become part of the enemy force. The commissions thus dispense with idea of personal culpability that has historically been critical to war crimes liability. In its place, the commissions provide a strict liability rule in which all members of the opposing side are committing a war crime simply by participating in armed conflict. The concerns generated by the commissions' approach are exacerbated by the absence of any requirement that prosecutions focus on the most serious offenders. In contrast to international tribunals, which have traditionally been required to pursue high-level perpetrators, ${ }^{78}$ commissions are free to pursue minor offenders, and have continued to do so.

Military commissions' expansive jurisdiction undermines the notion of war crimes as exceptional and dilutes the symbolic function of war crimes prosecutions. A principal motive for war crimes prosecutions under international law lies

\footnotetext{
${ }^{76}$ See Glazier, above n 70, 79-80.

${ }^{77}$ Ibid.

${ }^{78}$ SC Res 1329, 30 November 2000 (approving official policy of the ICTY and ICTR of prioritizing prosecution of 'civilian, military, and paramilitary leaders'). See also Danner \& Martinez, above n 44, 95-6.
} 
in their expressive value. ${ }^{79}$ The magnitude of the crimes, the multiple communities served, and the resource and political constraints on the number of prosecutions that can feasibly be brought, differentiate international criminal justice from domestic prosecutions. ${ }^{80}$ The crimes that are prosecuted-and the sentences imposed upon conviction-are laden with symbolic value. Sanctions imposed under the rubric of war crimes and other international law violations help craft historical narratives and embed normative values across borders. ${ }^{81}$ Those sanctions also communicate the outrage of the international community. ${ }^{82}$ The appropriate legal characterization of criminality under international criminal law thus provides 'a vocabulary that gives voice to the special gravity of the offense'. ${ }^{83}$

US military commissions seek to harness international criminal law's expressive purpose by characterizing the $9 / 11$ attacks and other wide-scale attacks against civilians by non-state actors as war crimes. But the commissions reach too far. By adopting a theory of liability that essentially permits one side to treat all enemy fighters as war criminals-regardless of their personal involvement in the commission of specific offences-military commissions undermine their own expressive aims. They minimize the stigma of being branded a war criminal and dilute the impact of prosecutions for actual violations of the law of war, such as wilful killing.

\section{$5 \quad$ Evading legality and due process}

The United States' attempt to prosecute MST and conspiracy as war crimes not only circumvents international criminal law's limits on substantive liability and requirement of personal culpability. It also contradicts the principle of legality by seeking to punish conduct that was not illegal at the time. The US government argues that MST and conspiracy charges against Guantanamo detainees do not run afoul of this principle-enshrined in domestic law under the Constitution's ex post facto clause-because both are offences traditionally triable by military

\footnotetext{
${ }^{79} \mathrm{M}$ Drumbl, Atrocity, Punishment, and International Law (2007) 173-9; C McCarthy, 'Victim Redress and International Criminal Justice' (2012) 10 JICJ 351, 365 (n 61).

${ }^{80}$ See R Sloane, 'The Expressive Capacity of International Punishment: The Limits of the National Law and Analogy and the Potential for International Criminal Law' (2007) 43 Stanford JIL 39, 40-42.

${ }^{81}$ See Drumbl, above n 78, 61, 173.

${ }^{82}$ Prosecutor v Aleksovski (Judgement) (ICTY, Appeals Chamber, Case No IT-95-14/1-A, 24 March 2000) para 185.

${ }^{83}$ Greenawalt, above n 23, 1092.
} 
commissions as part of the US common law of war. The government relies mainly on selective historical examples dating from the Civil War. ${ }^{84}$ Those examples, however, involved military commissions that exercised hybrid jurisdiction over domestic criminal offences based on martial law and over war crimes, ${ }^{85}$ or that involved charges alleging participation in a completed war crime. ${ }^{86}$ The Civil War tribunals, moreover, predated the development of the modern law of war. This section will not attempt a detailed analysis of the government's historical evidence, ${ }^{87}$ but rather will make two main points. First, even assuming there is some ambiguity regarding the meaning of this evidence-which is both temporally remote and fragmented-modern international criminal law cautions against expanding substantive liability in this manner. Second, charges such as MST and conspiracy-as well as other MCA offences that have a firmer basis in international law-demonstrate an attempt to circumvent the regular federal court system and channel cases to a specially created forum designed to provide defendants fewer protections and facilitate convictions. In this respect, the commissions diverge from internationally recognized guarantees afforded to the accused. They also lack a central justification for the creation of specialized tribunals in international criminal justice to address exceptionally grave criminality-the inability or unwillingness of existing domestic tribunals to prosecute the offences fully and fairly. Here, the existing democratic court system not only has the authority, but also has a demonstrated capability of prosecuting the very terrorism offences over which the commissions claim jurisdiction. ${ }^{88}$

The tension between substantive justice and legality is an old and recurring one in international criminal law. The former seeks to prohibit and punish dangerous or egregious conduct even if it was not legally prohibited when it was carried out. By contrast, the principle of legality-nullum crimen sine

\footnotetext{
${ }^{84}$ Supplemental Brief for the United States, Al-Bahlul $v$ United States, No 11-1324 (DC Cir, 2013) 16-17, <http://www.lawfareblog.com/wp-content/uploads/2013/01/GovernmentSupplemental-Brief-Al-Bahlul.pdf $>$ [accessed 7 November 2013].

${ }^{85}$ D Glazier, 'The Misuse of History: Conspiracy and the Guantánamo Military Commissions', Legal Studies Paper No 2013-27, 34-41<http://papers.ssrn.com/sol3/papers.cfm?abs tract_id $=2274502 \&$ download $=$ yes $>$ [accessed 7 November 2013].

${ }^{86}$ See Mudd v Caldera, 134 F.Supp 2d 138, 147 (DDC, 2001) (affirming, on later federal court review, the original military commission's determination that the defendant, Dr Samuel M Mudd, was properly convicted under the law of war for having 'aided and abetted President Lincoln's assassins').

${ }^{87}$ For a persuasive rebuttal of the government's evidence in support of its argument that conspiracy is part of a separate domestic common law of war, see Glazier, above n 84 .

${ }^{88}$ See Zabel \& Benjamin Jr, above $\mathrm{n} 34$.
} 
lege-permits the imposition of criminal liability against an individual only if he engaged in conduct that was regarded as a criminal offence under applicable law at the time. ${ }^{89}$

The struggle between these competing principles dates to the origins of modern international criminal law. At Nuremberg, prosecutors sought to charge Nazi officials with crimes of aggression and crimes against humanity even though neither was firmly rooted in international law. The IMT ruled that defendants could be punished for atrocities that the world recognized as abhorrent even if they were not strictly defined as criminal when committed. ${ }^{90}$ Robert Jackson, the chief prosecutor, maintained that the nature of international law at the time of the Nuremberg trial prevented rigorous application of the principle of retroactivity. ${ }^{91}$

Since Nuremberg, however, the principle of legality has become firmly rooted in international law. It is recognized in human rights treaties that define the rights of the accused. ${ }^{92}$ It is also reflected in international humanitarian law treaties, ${ }^{93}$ and is widely regarded to fall within Common Article 3's requirement-applicable in all armed conflicts-that trials 'afford all the judicial guarantees recognized as indispensable by civilized peoples.' ${ }^{94}$ The nullum sine principle has also been established in statutes creating international tribunals and in their case law. ${ }^{95}$ It has, in short, been transformed 'from a principle of justice to a binding rule of customary international law, applicable to international tribunals as well as to states. ${ }^{96}$

International criminal law, to be sure, is not static and requires space to develop. Some latitude is important given international criminal law's aspiration to address the most serious criminality and the potential for ambiguity inherent in its decentralized structure. As international criminal law is applied to new circumstances, existing offences and elements of those offences develop through a

\footnotetext{
${ }^{89}$ See Cassese, above n 28, 36-7.

${ }^{90}$ United States $v$ Göring (Judgment) (1946), in 1 Trial of the Major War Criminals Before the International Military Tribunal (1947) 171, 219.

91 B Meltzer, 'Remembering Nuremberg', in B Cooper (ed), War Crimes: The Legacy of Nuremberg (1999) 20, 23.

92 International Covenant on Civil and Political Rights, 16 December 1966, 999 UNTS 1719, Art 15 (ICCPR); Convention for the Protection of Human Rights and Fundamental Freedoms, 4 November 1950, 213 UNTS 222, Art 7 (ECHR); American Convention on Human Rights, 22 November 1969, 1144 UNTS 123, Art 9.

93 Third Geneva Convention, Art 99(1); Fourth Geneva Convention, Art 67.

${ }^{94}$ See Glazier, above n 70, 66.

${ }^{95}$ See e.g. Rome Statute, Art 22.

${ }^{96} \mathrm{~K}$ Gallant, The Principle of Legality in International and Comparative Criminal Law (2010) 405-6.
} 
process of interpretation and clarification. ${ }^{97}$ International tribunals, for example, have played a significant role in developing international law regarding crimes against women, including rape and other types of sex-related violence. ${ }^{98}$ But while courts may adapt existing offence to new circumstances, they may not simply create new crimes. Further, where faced with conflicting interpretations of a rule, courts should generally adopt the interpretation that favours the accused. ${ }^{99}$

Salim Hamdan's MST prosecution illustrates how military commissions circumvent the principle of legality. International law did not at the time (and does not now) criminalize providing oneself as personnel or serving as an armed bodyguard and driver-the conduct that formed the crux of the MST charge and conviction in Hamdan's prosecution. ${ }^{100}$ As noted above, the government's theory of the case-that Hamdan had provided support to unlawful combatants (or 'unprivileged belligerents', under present terminology)-would effectively criminalize any assistance to an opposing force during armed conflict.

Moreover, although US domestic criminal law would today appear to cover Hamdan's conduct under the federal MST statute, it did not clearly do so at the time in question. The amendments to the federal MST statute expressly giving it extraterritorial reach post-dated Hamdan's conduct. ${ }^{101}$ More importantly, providing 'service' and 'personnel' (defined as one or more individuals who may be or include oneself) to a designated terrorist organization-which formed the basis of the allegations against Hamdan-were not added to the federal MST statute until 2004, several years after the conduct in question. ${ }^{102}$

The MCA undermines the principle of legality not only by expanding the scope of substantive liability, but also by allowing the government to divert cases from the regular federal criminal court system to a specially created

\footnotetext{
${ }_{97}$ Prosecutor v Aleksovski (Judgment and Sentence) (ICTY, Appeals Chamber, 24 March 2000) para 127.

${ }^{98}$ See e.g. J Halley, 'Rape at Rome: Feminist Interventions in Criminalization of Sex-Related Offenses of Positive International Criminal Law' (2008) 30 Mi JIL 1.

${ }^{99}$ Rome Statute, Art 22(2).

${ }^{100}$ Military Commission Order No 2-09, 16 July 2009 (listing the charges).

${ }^{101}$ The federal statutes criminalizing MST-18 USC $\$ 2339 \mathrm{~A}$ and 18 USC $\$ 2339 \mathrm{~B}-$ did not clearly apply extraterritorially to non-US persons until October 2001 and December 2004, respectively: A Walen, 'A Punitive Precondition for Preventive Detention: Lost Status as a Foundation for Lost Immunity' (2011) 48 San Diego LR 1229, 1272 (n 149). For a critique of the broad extraterritorial reach of the current federal MST statute, see S A Solow, 'Prosecuting Terrorists as Criminals and the Limits of Extraterritorial Jurisdiction' (2011) 85 St John's LR 1483.

${ }^{102}$ Congress added these terms when it amended the MST statute in 2004. See 18 USC $\$ 2339 \mathrm{~A}(\mathrm{~b})$ (2004) (amending 18 USC $\$ 2339$ A(b) (1996)).
} 
tribunal that affords defendants fewer rights and protections. The commissions' forum-diversion potential is underscored by the possible prospective use of military commissions to prosecute offences such as MST that are prohibited under federal law-precisely the scenario envisioned by Judge Kavanaugh in his concurring footnote in Hamdan II. The MCA replicates an offence contained in the federal criminal code, thus giving the government the option of prosecuting the same conduct in a commission rather than a federal court as long as the defendant is subject to the commissions' personal jurisdiction as an 'alien unprivileged enemy belligerent.' ${ }^{\prime} 3$

The potential for forum-diversion is present even in the handful of instances where the alleged conduct of a Guantanamo detainee may constitute a law-of-war violation, as in the case of Khalid Sheikh Mohammed and four other defendants accused of attacking civilians on 9/11. These individuals could have been prosecuted in federal court not only under various domestic anti-terrorism statutes, but also under the War Crimes Act. ${ }^{104}$ Enacted in 1996 to implement the Geneva Conventions, this federal statute provides jurisdiction over war crimes committed by or against US nationals. The MCA, in short, permits the government both to criminalize conduct that was not illegal at the time by labelling it a 'domestic war crime' and to divert the prosecution of actual war crimes to a specialized forum to more easily obtain a conviction, limit a defendant's rights, and minimize public access despite existing war-crimes jurisdiction in the regular domestic courts.

The creation of a specialized forum for terrorism prosecutions brings the commissions into conflict with fair-trial guarantees established under international law, notwithstanding the Obama administration's efforts to reform the commissions. Common Article 3, which applies to the US armed conflict against al Qaeda and associated forces, requires the use of 'regularly established courts' and protects against specially created tribunals that do not follow accepted international standards. While Common Article 3 itself does not define the specific requirements of a regularly constituted court, the procedural protections for individuals tried during armed conflict contained in Article 75 of the First Additional Protocol to the Geneva Conventions, which are considered to be customary international law, provide additional guidance. ${ }^{105}$ Further, human rights law, which is generally considered to provide standards for international criminal tribunals, ${ }^{106}$

\footnotetext{
${ }^{103} 10$ USC $\$ \$ 948 \mathrm{a}, 948 \mathrm{c}$.

${ }^{104} 18$ USC $\$ 2441$.

${ }^{105}$ D Jinks, 'September 11 and the Laws of War' (2003) 28 Yale JIL 1.

${ }^{106} \mathrm{~K}$ Watkin, 'Controlling the Use of Force: A Role for Human Rights Norms in Contemporary
} 
contains specific guarantees that must be provided to the accused, including the presumption of innocence, the right to counsel, the right to be tried without delay, and the right of the accused to examine witnesses appearing against him and to call witnesses in his favour. ${ }^{107}$ While the 2009 MCA, as written, appears to comport with several of these guarantees, deviations in practice have been significant. For example, the US Department of Defense has undermined effective representation of counsel through limitations on attorney-client communications and by giving less favourable treatment to defence requests for expert testimony and other trial-related expenses than to similar requests by the prosecution. ${ }^{108}$ The MCA also denies defendants' their choice of counsel, limiting defence counsel to US military judge advocates and civilians who are US citizens. ${ }^{109}$

Transparency, moreover, remains a significant problem in the military commissions. Not only has the government sought to censor detainee testimony regarding their own mistreatment by US officials, but an unnamed US government agency was recently discovered to possess the power to secretly censor the feed of the proceedings that the public and news media receive on a 40 -second delay-all apparently without the knowledge of the presiding military judge. ${ }^{110}$ The commissions have conducted closed hearings to discuss legal issues regarding classified information, also from which the defendant himself is excluded. ${ }^{111}$ Although the MCA expressly bars the admission of evidence obtained by torture and other coercion, ${ }^{112}$ this protection is jeopardized by the government's misuse of the classification process, restrictions on the identification of, and access to, potential witnesses, and limitations on discovery, all of which inhibit a defendant from demonstrating that a particular statement was coerced. ${ }^{113}$

The larger picture that emerges is of a shadow criminal justice system without fixed rules or an internalized commitment to principles of legality and due

Armed Conflict' (2004) 98 AJIL 1, 2-8; K A Petty, 'Beyond the Court of Public Opinion: Military Commissions' (2011) 42 Georgetown JIL 303, 348-9.

${ }^{107}$ ICCPR Art 14.

${ }^{108}$ See Glazier, above n 70, 103-6.

${ }^{109} 10$ USC $\$ \$ 948 \mathrm{k}, 949 \mathrm{c}$.

${ }^{110} \mathrm{C}$ Savage, 'Judge Stops Censorship in Sept. 11 Case', New York Times, 31 January 2013, <http://www.nytimes.com/2013/02/01/us/politics/9-11-judge-orders-end-to-outside-go vernment-censors.html?_r $=0>$ > [accessed 7 November 2013].

${ }^{111}$ B Fox, 'Guantanamo Court Held in Secret Without Accused', Associated Press, 14 June 2013, $<$ http://bigstory.ap.org/article/guantanamo-court-held-secret-without-accused> (accessed 7 November 2013).

${ }^{112} 10$ USC $\$ 948 \mathrm{r}(\mathrm{c})$.

${ }^{113}$ Glazier, above n 70, 109. 
process. ${ }^{114}$ The commissions' improvised nature infects nearly every aspect of their proceedings, undermining their integrity and fairness. ${ }^{115}$

International criminal law has historically relied on the creation of new tribunals to prosecute offences, from the IMT at Nuremberg to ad hoc tribunals (ICTY and ICTR), hybrid tribunals (such as the Extraordinary Chambers in the Courts of Cambodia and Special Tribunal for Lebanon), and now a permanent criminal court at The Hague. These tribunals are predicated on the assumption that existing domestic courts are incapable or unwilling to prosecute offences that the international community deems sufficiently grave to warrant judgment and punishment-an assumption best embodied by the Rome Statute's complementarity principle. ${ }^{116}$ A different impulse, however, underlies the creation of the Guantanamo military commissions. Under the pretext of war crimes, the commissions create a specialized tribunal whose main purpose is not to adjudicate conduct that the regular domestic courts-whether Article III civilian courts or military courts-martial-lack the capacity to address. Rather, they provide an escape valve for cases the government wishes to prosecute in a geographically remote, lower-process forum, whether because its evidence is too weak or tainted to support a conviction in the regular federal courts or because trying the defendants in the United States is considered too politically controversial.

Like the military commissions' substantive overbreadth in defining offences, the commission' procedural deficiencies undermine the expressive function served by war crimes prosecutions. Adherence to legality and due process helps avoid perceptions of bias and victor's justice. ${ }^{117}$ It also helps maintain the focus on the alleged conduct rather than on the denial of judicial guarantees. The exclusion of US citizens from the jurisdiction of Guantanamo military commissions exacerbates this problem by reinforcing asymmetries between fora, with the more rights-protective federal criminal courts reserved for citizens of the prosecuting state and less rights-protective military tribunals designated exclusively for foreign nationals. Whereas international criminal justice seeks to express condemnation of egregious conduct through prosecution in a capable, but neutral forum, the Guantanamo military commissions attempt to convey

\footnotetext{
${ }^{114}$ See E R Fidell, 'Charm Offensive in Lilliput: Military Commissions 3.1' (2012) 56 Saint Louis Univ LJ 1177.

${ }^{115}$ D Martin, 'Judicial Review and the Military Commissions Act: On Striking the Right Balance' (2007) 101 AJIL 344, 358.

${ }^{116}$ Rome Statute, Art 17.

${ }^{117}$ M A Drumbl, 'The Expressive Value of Prosecuting and Punishing Terrorists: Hamdan, the Geneva Conventions, and International Criminal Law' (2007) 75 George Washington LR 1165, 1188.
} 
opprobrium by shifting a category of cases away from a capable, but neutral forum (federal courts) to a second-class forum-a message embodied by the common refrain that foreign terrorism suspects do not 'deserve' to be tried in the regular court system.

\section{Conclusion}

This paper has explained how the prosecution of offences by military commissions at Guantanamo clashes with the conceptualization and treatment of war crimes under international law. It has described several problems flowing from the United States' position that it may try by military commission offences, such as MST and conspiracy, that are not recognized as war crimes under international law based on the notion of a separate US common law of war. In defending the government's position that it may-at least prospectively-treat MST as a war crime, Judge Kavanaugh noted that the 'United States may be a leader in the international community, not just a follower.' ${ }^{18}$ This view of the United States as a norm entrepreneur is problematic even aside from the constitutional limitations on Congress' power to define offences triable by military commissions. By expanding the scope of criminal liability so broadly in order to secure convictions, the United States undermines the meaning and purpose of designating conduct a war crime and prosecuting it on that basis.

${ }^{118}$ Hamdan II, 480. 